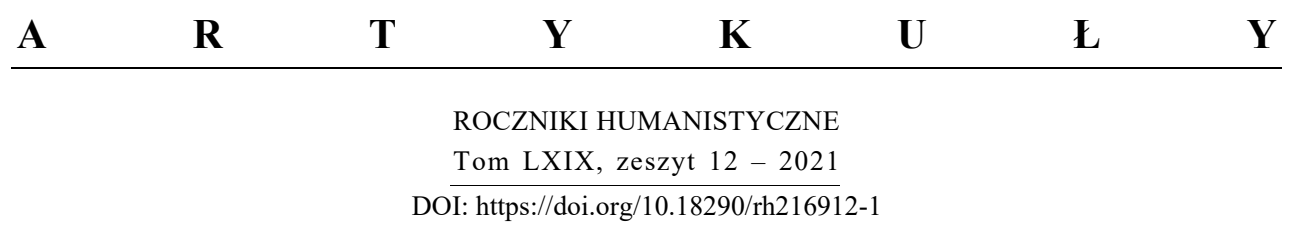

JULIA PALACZ

\title{
WCZESNE WŁOSKIE KONCERTY KLAWISZOWE FRANCESCA DURANTEGO
}

Historia koncertu na instrument klawiszowy związana jest ściśle ze stopniowymi przemianami funkcji, jaką instrument ten pełnił w utworach zespołowych. Przed osiemnastym wiekiem była to funkcja przede wszystkim realizowania akompaniamentu. Początków stosowania go w obsadzie w roli melodycznej i niezależnej partii, współwystępującej z innymi instrumentami, upatruje się zwykle w twórczości Georga Friedricha Haendla oraz Johanna Sebastiana Bacha: w solowej partii organów w Sonacie z Il trionfo del Tempo e del Disinganno, w koncertach klawesynowych BWV 972-987 czy w piątym Koncercie brandenburskim (Butt 93-96). Koncerty solowe na klawesyn z orkiestrą występują licznie w twórczości kompozytorów z krajów niemieckich, wliczając słynne dzieła Carla Philippa Emanuela Bacha, pisane od lat trzydziestych osiemnastego wieku. Ważnym ośrodkiem kultywowania tego gatunku był także Londyn, gdzie wśród licznych utworów publikowanych dla szerszego grona odbiorców znajdowały się również te autorstwa kompozytorów włoskich, przebywających poza Italią: Giovanniego Battisty Sammartiniego (1754), Pietra Domenica Paradisiego (1768), Vincenza Ciampiego (1756) czy Tommasa Giordaniego (1776, 1779). Koncerty klawiszowe powstawały w osiemnastym wieku jednak także na terenie dzisiejszych Włoch, kraju uznawanego za ojczyznę koncertu instrumentalnego, choć nie zyskały $w$ literaturze przedmiotu takiej popularności, jak te autorstwa

JUlia PALACZ - studentka w Instytucie Muzykologii Uniwersytetu Jagiellońskiego; adres do korespondencji: ul. Westerplatte 10, 31-033 Kraków; e-mail: julia.palacz8@gmail.com; ORCID: https://orcid.org/0000-0001-5008-0975.

Julia Palacz, student at the Jagiellonian University, Institute of Musicology; address for correspondence: ul. Westerplatte 10,31-033 Kraków, Poland; e-mail: julia.palacz8@gmail.com; ORCID: https://orcid.org/0000-0001-5008-0975. 
Wolfganga Amadeusza Mozarta czy synów Bacha. Jednym z pierwszych twórców dzieł tego gatunku w Italii był działający w Neapolu Francesco Durante (Zanetti 1097, Freeman 122, Heller 242) - autor przywoływanego w literaturze Koncertu B-dur, którego rękopis datowany został przez Francesca Degradę na ok. 1750 rok (153). Do naszych czasów zachowały się jednak niekompletnie jeszcze dwa inne koncerty klawesynowe tego kompozytora, które do tej pory nie były przedmiotem zainteresowania badaczy, często również nie zostawały w ogóle uwzględniane w dorobku kompozytora (np. Harris 20). Dzieła te - napisane przez twórce o rok starszego od wspomnianych Bacha i Haendla, działającego w istotnym dla ówczesnej kultury muzycznej ośrodku - dostarczają cennych informacji o historii kompozycji i praktyki wykonawczej tego gatunku. Wszystkie trzy znane dzisiaj koncerty klawiszowe autorstwa Francesca Durantego są zatem łącznie przedmiotem niniejszego artykułu. Przeprowadzona została w nim analiza ich cech stylistycznych oraz sposobów kształtowania poszczególnych partii, która umożliwiła porównanie utworów między sobą, a także odniesienie ich względem szerszego kontekstu historii koncertu instrumentalnego.

Francesco Durante (ur. 1684 we Frattamaggiore, Aversa, zm. 1755 w Neapolu) zasłynął przede wszystkim jako uznany kompozytor sakralnej muzyki wokalnej. W jego dorobku znajdują się dzieła liturgiczne i religijne wszystkich gatunków, a jednocześnie zaledwie kilka dzieł dramatycznych, co było dość nietypowe dla ośrodka neapolitańskiego. Ponadto Durante był uznanym nauczycielem, jednym z najbardziej cenionych w Neapolu. Sam w latach 1702-1705 uczył się w neapolitańskim Conservatorio di Sant'Onofrio a Capuana, następnie od 1728 roku przez dziesięć lat pełnił funkcję primo maestro w Conservatorio dei Poveri di Gesù Cristo, zastępując na tym stanowisku samego Gaetana Greca. Tę samą funkcję sprawował również od 1742 roku w Conservatorio di Santa Maria di Loreto, a od roku 1745 jednocześnie w Conservatorio di Sant'Onofrio. Jego uczniowie wypowiadali się o nim zawsze w jak najlepszych słowach; byli wśród nich tacy późniejsi słynni kompozytorzy, jak Giovanni Battista Pergolesi czy Giovanni Paisiello (Dietz 739-741).

Utwory instrumentalne stanowią mniejszość w twórczości Durantego, należy do niej przede wszystkim dziewięć Concerti a quattro na zespół smyczków oraz solowe sonaty i toccaty klawesynowe. $\mathrm{Z}$ działalnością dydaktyczną kompozytora związany jest m.in. zbiór Sonate per cembalo divisi in studii e divertimenti (Neapol, 1747-1749). Adresatem jego dedykacji był Giacomo Francesco Milano, książę Ardore, będący uczniem Durantego, a ponadto utalentowanym klawesynistą, którego umiejętności w zakresie improwizacji podkreślają relacje z epoki (Costantini i Magaudda). Być może z myślą o nim właśnie powstały trzy zacho- 
wane koncerty klawiszowe. $Z$ drugiej strony mogły być one przeznaczone również dla uczniów któregoś z trzech konserwatoriów, w których Durante nauczał.

Koncert B-dur zachował się w trzech przekazach - w formie głosów w Biblioteca dell'Abbazia di Montecassino (sygn. 7-A-28/6) oraz w dwóch partyturach: w Neapolu w Biblioteca del Conservatorio di Musica S. Pietro a Majella (sygn. M.S. 1886) i w Wenecji w Biblioteca del Conservatorio di Musica Benedetto Marcello (sygn. Torrefranca Ms.B. 5d) ${ }^{1}$. Dwa pozostałe - Koncert $A$-dur i Koncert C-dur - zachowane są niekompletnie w Biblioteca dell'Abbazia di Montecassino (sygn. 7-A-28/12 dla pierwszego, 7-A-28/7 dla drugiego); oba przekazy są unikatowe i w formie głosów. W Koncercie A-dur w części pierwszej jedynie w siedmiu ostatnich taktach brak partii klawesynu, natomiast z części drugiej zachowały się już tylko partie skrzypiec pierwszych i basso, z części trzeciej - skrzypiec pierwszych, drugich i basso. Z Koncertu $C$-dur zachowana jest jedynie partia klawesynu. Wszystkie wymienione rękopisy nie są uznawane za autografy, ponadto nie są one również datowane wyjątek stanowi wenecki przekaz Koncertu B-dur, będący kopią partytury z Neapolu, w którym inskrypcja wskazuje na rok 1863.

Biorąc pod uwagę lata działalności Durantego, czas skomponowania wszystkich trzech koncertów określić można na pierwszą połowę osiemnastego wieku (przed 1755 rokiem). W przypadku jedynego omawianego dotąd w literaturze Koncertu B-dur, Francesco Degrada - jak zostało już wspomniane - uściśla datowanie partytury z Neapolu na ok. 1750 rok (153). Papier, na którym sporządzone zostały rękopisy, nie był w ramach niniejszego artykułu badany.

Obsadę Koncertu B-dur i Koncertu A-dur stanowią, oprócz solisty, dwoje skrzypiec i partia instrumentu realizującego podstawę basową. W rękopisie Koncertu B-dur obsada ta jest określona na stronie tytułowej („Per Cembalo con V:V: "ni e Basso"), w Koncercie A-dur natomiast, zatytułowanym „Concerto di Cembalo”, na kolejnych kartach pojawiają się nazwy głosów: „Violino Primo”, „Violino Secondo” i „Basso”. W obsadach obu utworów brak partii altówki, co spotykane jest dość często u kompozytorów neapolitańskich, a także na terenie Anglii - do czasów Jana Christiana Bacha powstało tam około 300 koncertów klawiszowych z orkiestrą ograniczoną do dwojga skrzypiec i partii basowej, co - jak stwierdza Walter Kolneder - zapewne powodowane było względami praktycznymi (369). O pełnej obsadzie nie informuje natomiast rękopis Koncertu C-dur, gdzie na karcie tytułowej widnieje jedynie „Concerto per Cembalo" i nazwa głosu „Cembalo”.

\footnotetext{
${ }^{1}$ Niniejszy artykuł bazuje na przekazie z Neapolu. Współczesne wydanie tego koncertu: Francesco Durante. Concerto in si bemolle, per clavicembalo e archi, red. Francesco Degrada, Ricordi, 1968.
} 
W przypadku partii skrzypiec brak jest większych wątpliwości co do stosowanego instrumentu, także pojawiające się w źródłach cembalo wskazywałoby dość jednoznacznie na klawesyn, a nie inny instrument klawiszowy. Co prawda pianoforte stawały się $\mathrm{w}$ osiemnastym wieku coraz bardziej popularne, jednak w praktyce wykonywania koncertów klawesyny były częstszym wyborem co najmniej do lat osiemdziesiątych (Stowell 195). Największe wątpliwości co do obsady związane są z partią basso continuo. W tytule Koncertu $B$-dur oraz w głosach Koncertu A-dur jest ona określona jako „Basso”, w partyturze Koncertu $B$-dur natomiast została zapisana na osobnej pięciolinii, odrębnej od partii klawesynu, z adnotacją „Controbasso” na początku. Problem określania instrumentów realizujących podstawę basową jest złożony, głównie z powodu ówczesnej różnorodności instrumentów smyczkowych o rejestrze basowym i ich niekonsekwentnego nazewnictwa w źródłach. Przyjmując, że w tym przypadku faktycznie chodziło o kontrabas, instrument szesnastostopowy, przy transponowaniu o oktawę w dół w Koncercie B-dur ambitus jego partii sięgałby do dźwięku $\mathrm{F}_{1}$, a w Koncercie A-dur - do $\mathrm{E}_{1}$. Jednocześnie uważa się, że na początku osiemnastego wieku we Włoszech typowe kontrabasy miały zwykle trzy struny, z których najniższa była strojona do dźwięku $A_{1}$ lub $G_{1}$, a struna $E_{1}$ nie została jeszcze wprowadzona powszechnie w tym stuleciu (Slatford i Shipton 522). Określenie „controbasso” pojawia się dość często w źródłach pochodzących z Neapolu, występuje m.in. także w koncertach klawiszowych autorstwa Domenica Auletty ${ }^{2}$ - w jego Koncercie G-dur ambitus tej partii sięgałby już dźwięku $\mathrm{C}_{1}$. Zastosowanie kontrabasu byłoby w tych przypadkach możliwe, o ile używano instrumentów z dodatkowymi, niższymi strunami bądź też te najniższe dźwięki grane były o oktawę wyżej. Z kolei Richard Maunder stwierdza, wspominając w swojej pracy o koncertach klawiszowych Durantego i Auletty, że partia basowa wykonywana była w nich zapewne przez wiolonczelę ${ }^{3}(161)$, zatem instrument ośmiostopowy.

Pod względem formy koncerty klawiszowe Durantego wykazują podobieństwo do weneckiego koncertu trzyczęściowego, ze skrajnymi częściami w tempach szybkich oraz wolną częścią środkową w kontrastowej tonacji. W częściach skrajnych, co również typowe dla koncertu weneckiego od czasów

${ }^{2}$ Zachowane w Neapolu w Biblioteca del Conservatorio di Musica S. Pietro a Majella, sygn. M.S. 30-32.

3 ,,[T]here are a few [concertos] by Domenico Auletta and Francesco Durante, including harpsichord concertos of c. 1750 accompanied by just two violins and «Basso» (presumably cello) [...]”. Właściwie można mieć wątpliwość, czy autor nie wziął pod uwagę pojawiających się w rękopisach określeń „controbasso”, czy też pomimo ich obecności uznał partię za odpowiednią do realizacji bardziej przez wiolonczelę niż kontrabas. 
Vivaldiego, dostrzegalne jest stosowanie zasad formy ritornelowej, także w częściach zachowanych w niekompletnej obsadzie - w Koncercie A-dur można w nich wyróżnić ritornele z powracającymi w smyczkach motywami, przedzielone fragmentami z pauzami całotaktowymi bądź z akordowym akompaniamentem; w Koncercie C-dur z kolei widoczne są kolejne epizody solowe przedzielone odcinkami basso continuo. Forma ta występowała w niekompletnych koncertach prawdopodobnie również w wolnych częściach środkowych (tutaj z mniejszą liczbą wystąpień solisty).

Tabela 1. Koncerty klawiszowe Francesca Durantego: tempo, metrum, tonacja i liczba taktów poszczególnych części

\begin{tabular}{lcccccccccccc}
\multicolumn{3}{c}{ Koncert B-dur } & \multicolumn{4}{c}{ Koncert A-dur } & \multicolumn{5}{c}{ Koncert C-dur } \\
\hline Allegro & c & B & 82 & Allegro & $3 / 8$ & A & 169 & Allegro & c & C & 133 \\
Grave & c & g & 18 & Largo & $3 / 8$ & a & 96 & Andante & $3 / 8$ & a & 112 \\
Allegro & $3 / 8$ & B & 115 & Allegro assai & c & A & 80 & Presto & c & C & 245
\end{tabular}

Po uwzględnieniu różnic metrum zauważyć można, że część pierwsza Koncertu B-dur i finał Koncertu A-dur, mające niemal identyczne rozmiary, są najobszerniejszymi częściami tych koncertów. Jednocześnie w całości Koncert $A$-dur jest bardziej rozbudowany, część środkowa jest tu dwukrotnie dłuższa (stanowiąc jedną piątą objętości całego cyklu). Znaczne rozbudowanie poszczególnych części najwyraźniej zwraca jednak uwagę w Koncercie C-dur, gdzie kolejne odcinki formalne są dłuższe i mają bardziej złożony plan harmoniczny. W części pierwszej początkowy ritornel zajmuje 24 takty, w finale - 43, podczas gdy analogiczny odcinek rozpoczynający Koncert B-dur liczy 10 taktów, a Koncert A-dur - 18 i pół taktu.

Partia klawesynu w odcinkach solowych przede wszystkim eksponuje biegłość techniczną wykonawcy: zostały w niej zastosowane figuracje w drobnych wartościach rytmicznych, pochody równoległych tercji i sekst, tryle, pasaże, odległe skoki dźwięków pomiędzy oktawami, krzyżowanie partii obu rąk, a także pasaże i figuracyjne motywy przechodzące między tymi partiami. Zabiegi te wpisane są ściśle w specyfikę instrumentu i występują powszechnie także w solowych sonatach klawesynowych z tego okresu. Ponadto fragmenty solowe w dużej mierze mają charakter swobodnej improwizacji, co widoczne jest zwłaszcza w częściach utrzymanych w wolnym tempie, kiedy kolejne frazy melodyczne wynikają jedna z drugiej - każda kolejna stanowi wariacyjną mo- 
dyfikację poprzedniej. Partia klawesynu przypomina zatem zapis improwizacji, i to zapis dość dokładny, jak np. w części środkowej Koncertu C-dur, gdzie rozpisane zostały przednutki i ozdobniki nawet sześćdziesięcioczwórkowe. W tej samej części na zakończenie ostatniego wystąpienia solisty pojawia się również zapisana bez kresek taktowych krótka cadenza $a^{4}$. Wczesne koncerty klawiszowe wydają się zatem być silnie związane z istniejącą wcześniej praktyką improwizacji, o której to praktyce, ze względu na brak utrwalenia w zapisie, możemy dzisiaj ewentualnie jedynie wnioskować ${ }^{5}$.

W Koncercie B-dur i Koncercie A-dur na partię solową składają się przede wszystkim efektowne figuracyjne przebiegi, które jeśli nawiązują w ogóle do materiału melodycznego ritorneli, to w bardzo odległy sposób - motto bywa czasem jednie zasugerowane $\mathrm{w}$ epizodach. Jeśli natomiast przyjrzeć się partii solowej Koncertu C-dur, to zauważyć można, że jest ona zdecydowanie bardziej tematyczna, a poza figuracyjnymi przebiegami występują w niej także krótkie myśli melodyczne, ujęte w oddzielne frazy. Akompaniament ritornela początkowego części pierwszej tego koncertu oraz plan harmoniczny pierwszego wystąpienia solisty wykazują znaczne podobieństwo, co w połączeniu z liniami melodycznymi partii klawesynu prowadzi do wniosku, że epizod prawdopodobnie dość dokładnie powtarzał tym razem materiał tematyczny z początkowego tutti. Epizody i ritornele w tym koncercie mogły być ze sobą powiązane tematycznie w większym stopniu niż $w$ dwóch pozostałych utworach, co jest istotną cechą. Powiązania takie występują nieraz w koncertach Antonia Vivaldiego, nie stanowiąc u niego jednak reguły (Talbot 170). Prezentowanie tematu otwierającego także na początku epizodów stało się natomiast zasadą dla koncertów późniejszych i stylu wczesnoklasycznego. W koncertach m.in. Giuseppe Tartiniego i jego ucznia, Pasqualina Biniego, spotkać można przykłady monotematycznych części, w których - jak stwierdza Chappel White - temat początkowy jest wręcz nadmiernie powtarzany (69).

\footnotetext{
${ }^{4}$ Tak szczegółowe utrwalenie partii solowej wskazywałoby na przeznaczenie rękopisu z koncertem dla wspomnianych celów dydaktycznych.

${ }^{5}$ Roberto Zanetti stwierdza, że włoscy wirtuozi, będący autorami licznych klawiszowych utworów solowych, zapewne łączyli gatunek koncertu raczej z konkretnym, jednorazowym występem opartym na improwizacji, stąd brak zapisu takich utworów sprzed 1740 roku (1095).
} 


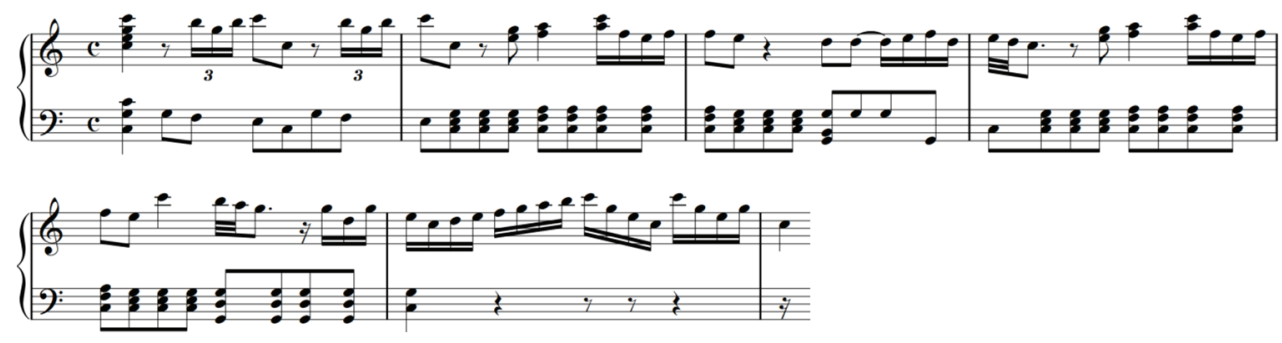

Przykład 1. Początek pierwszego epizodu solowego z cz. I Allegro z Koncertu C-dur (t. 25-31)

W przypadku koncertów klawesynowych zwyczajem było, że solista prowadził jednocześnie całe wykonanie i grał również w odcinkach tutti, akompaniując orkiestrze (Kolneder 363). W partii klawesynu omawianych koncertów zapisana została zatem także linia basso continuo dla odcinków orkiestrowych (wszędzie bez cyfrowania). Wraz z klawesynem partię basso continuo wykonywał drugi instrument - wspomniany już głos „Basso” bądź „Controbasso”, którego partia $\mathrm{w}$ ritornelach pokrywa się z linią akompaniamentu u solisty, zyskuje natomiast odrębny materiał w odcinkach, w których solowy klawesyn gra $\mathrm{z}$ akompaniamentem całego zespołu.

Melodycznymi partiami orkiestrowymi w omawianych koncertach są skrzypce pierwsze i skrzypce drugie, przy czym pomiędzy Koncertem B-dur a Koncertem A-dur zauważyć można różnicę w traktowaniu tych partii. W pierwszym są one różnicowane, a poza fragmentami granymi homorytmicznie występują też frazy powierzane tylko jednym skrzypcom - sama fraza otwierająca koncert przechodzi płynie ze skrzypiec pierwszych do drugich. W części Grave tego koncertu repryzę tematu głównego rozpoczynają solowo skrzypce pierwsze, one również kończą całą część, powtarzając ostatnią frazę za partią klawesynu; z kolei w ostatniej części do faktury wprowadzone zostają imitacje. Co ciekawe, podobieństwo do tego finału odnaleźć można w innym utworze Durantego - Koncercie A-dur na smyczki a quattro $^{6}$. W jego części czwartej, Canone a tre, występuje podobny motywicznie temat otwierający, ponadto część ta również utrzymana jest $\mathrm{w}$ metrum $3 / 8 \mathrm{i}$ ma postać formy binarnej. Porównując obie części zaobserwować można, jak podobny pomysł formalnomotywiczny zyskuje inną realizację w zależności od obsady - w części $C a$ none a tre stanowi ją zespół smyczków a quattro (altówka dwoi tu w oktawach partię basową). Tworzy on jednorodną imitacyjną fakturę, przez co część jest krótsza i ma bardziej zwartą budowę. W koncercie na klawesyn forma została

\footnotetext{
${ }^{6}$ Zachowany m.in. w zbiorze koncertów w Neapolu w Biblioteca del Conservatorio di Musica S. Pietro a Majella (sygn. M.S. 1882-1885). Szósty koncert we współczesnym wydaniu: Francesco Durante. Concertos pour orchestre a cordes, red. Roger Blanchard, Heugel, 1970.
} 
urozmaicona figuracyjnymi popisowymi odcinkami solowymi, przez co brzmienie całości uległo zupełnej zmianie. Imitacja inicjalna występuje tu między skrzypcami pierwszymi i drugimi, w odcinku repryzowym wprowadzona została również pomiędzy partiami obu rąk solisty, jest ona jednak bardziej swobodna. Sam temat uległ modyfikacji, przybierając formę krótkiego motta ze swobodnym rozwinięciem opartym na progresyjnych repetycjach motywu. Warto podkreślić, że przy braku datowania rękopisów obu koncertów trudno jednoznacznie stwierdzić, która wersja stanowiła w tym przypadku pierwowzór.
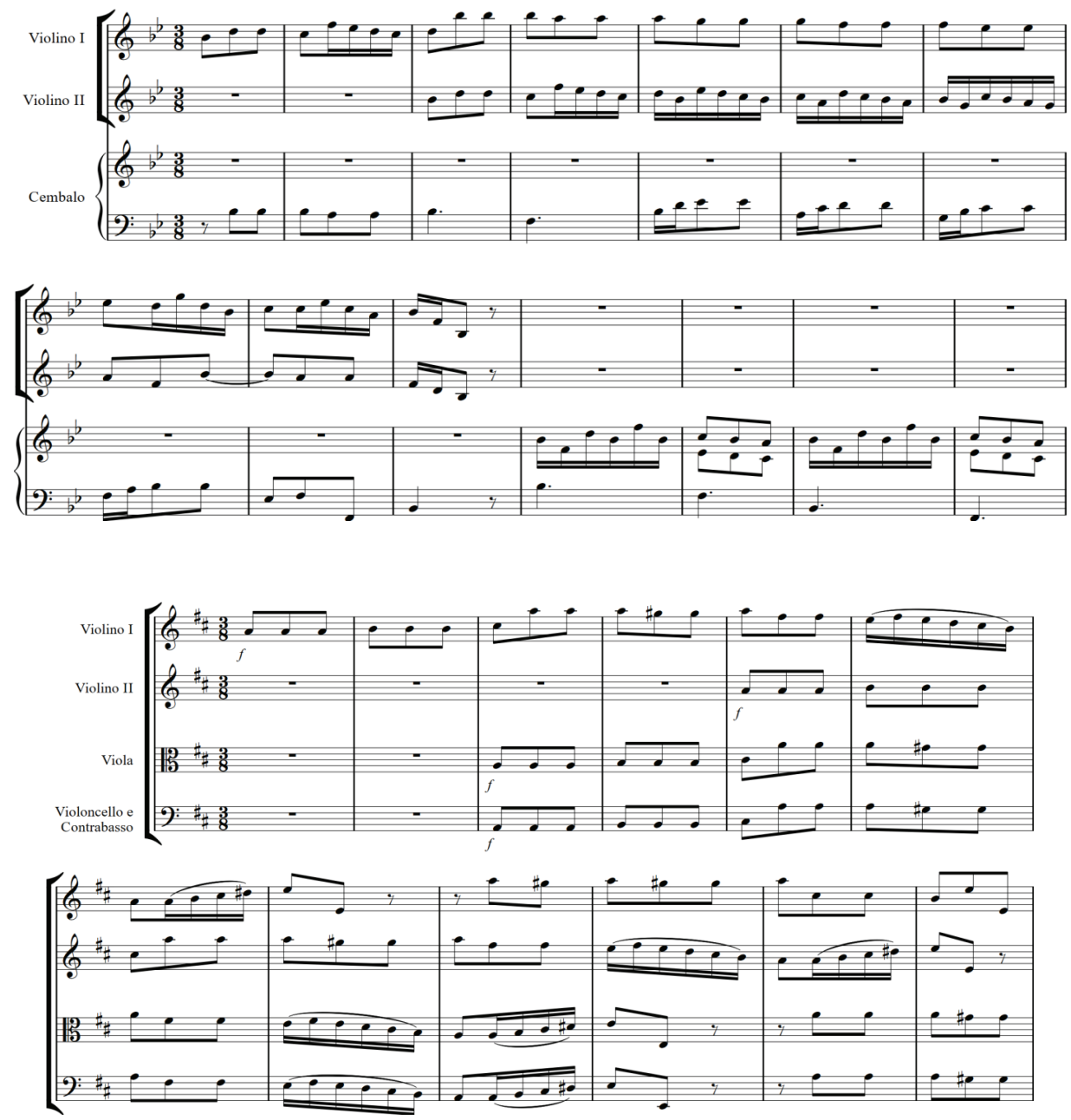

Przykład 2. Porównanie początku cz. III Allegro z Koncertu B-dur (t. 1-14) oraz cz. IV Canone a tre z Koncertu A-dur na smyczki (t. 1-12, na podst. Francesco Durante, Concertos 110-11) 
W Koncercie A-dur faktura orkiestry została już znacznie uproszczona partie dwojga skrzypiec tworzą wspólnie całość, są prowadzone stale w równoległych tercjach lub w unisonie. Uproszczenie to uznać można za cechę wczesnoklasyczną, występującą także m.in. w koncertach Tartiniego pisanych po 1750 roku (White 107). Wpływy stylu galant widoczne są również w materiale tematycznym, prezentowanym w ritornelach przez skrzypce, a w Koncercie C-dur także przez klawesyn - linie melodyczne są tu oparte na dość prostych, łatwo zapadających w pamięć motywach, należących do pewnego obiegowego repertuaru. W ritornelach zauważalna jest segmentacja przebiegu w krótkie, kilkutaktowe frazy, dość czytelnie wydzielone od siebie. Najczęściej są one również konstruowane symetrycznie, przez repetycję motywów.

Partie smyczków towarzyszą nieraz również wystąpieniom solisty - udział orkiestry w epizodach, a także solisty w odcinkach orkiestrowych sprawia, że teoretyczne odcinki formy nie są już tak wyraźnie odrębne, jak przeważnie miało miejsce w najwcześniejszych koncertach solowych. W początkowym Allegro z Koncertu B-dur pojawiają się odcinki przejściowe między ritornelami a epizodami, kiedy już $\mathrm{w}$ trzecim takcie ritornela do orkiestry płynnie dołącza solista, smyczki przechodzą w akompaniament i dopiero po kadencji następuje typowy figuracyjny epizod solowy bez akompaniamentu. Z kolei w pierwszej części Koncertu A-dur zaobserwować można fragmenty, w których współwystępowanie akompaniamentu orkiestry i jednostajnych ostinatowych figuracji klawesynu sprawia, że partia solowa wtapia się w brzmienie zespołu, a odcinek taki nie stanowi ani typowego ritornela, ani epizodu. Ponadto w koncercie tym zwraca uwagę stosowanie w epizodach solowych krótkich „wstawek" smyczków - pojedynczych motywów granych przez dwoje skrzypiec unisono, wchodzących $\mathrm{w}$ dialog $\mathrm{z}$ partią solisty, a jednocześnie tworzących pewne cezury w przebiegu i podkreślających daną tonację osiąganą chwilowo w modulujących figuracjach klawesynu. W odniesieniu do takich przerywników tutti w epizodach Chappel White stwierdza, że we Włoszech występowały one tylko do pewnego momentu - można je spotkać nieraz w koncertach Vivaldiego i jego naśladowców oraz w koncertach skrzypcowych Tartiniego z wczesnego i środkowego okresu twórczości, natomiast brak ich w późnych utworach tego kompozytora, jak też innych włoskich twórców, którzy zaadaptowali wczesny styl galant (54). 

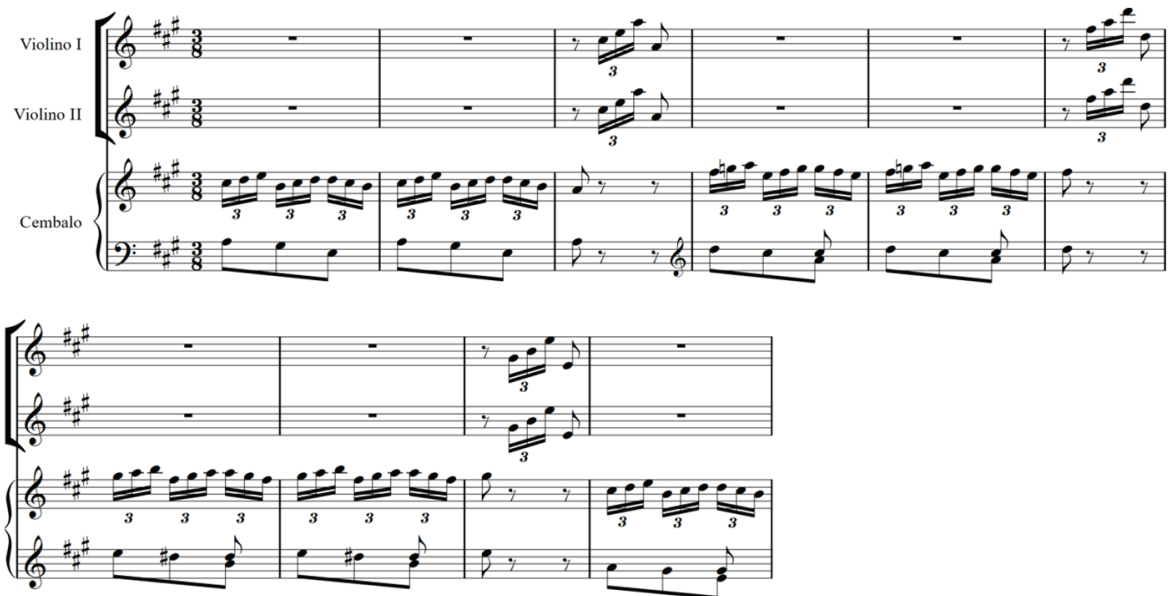

Przykład 3. Fragment cz. I Allegro z Koncertu A-dur (t. 109-118)

Analiza i porównanie zachowanych partii wszystkich trzech znanych dzisiaj koncertów klawiszowych Francesca Durantego pozwala zatem zaobserwować występujące pomiędzy utworami różnice stylistyczne - świadczą one o zmianach, jakie następowały $\mathrm{w}$ tym gatunku w pierwszej połowie osiemnastego wieku i wiązane są zwykle $\mathrm{z}$ twórczością kompozytorów z krajów niemieckojęzycznych. Obecność tych różnic wskazywałyby na to, że omówione dzieła powstawały w różnym czasie: Koncert $B$-dur, wykazujący najwięcej podobieństw do wczesnych koncertów instrumentalnych, prawdopodobnie skomponowany został wcześniej niż dwa pozostałe utwory, tym samym bliżej początku osiemnastego wieku. Koncert A-dur, ze „wstawkami” smyczków w epizodach i nietematyczną partią solową, byłby wówczas relatywnie późniejszy, natomiast odmienny charakter partii solowej w Koncercie C-dur pozwala przypuszczać, że utwór ten być może powstał najpóźniej. Ponadto obecne w badanych kompozycjach cechy, które odwołują do wcześniejszych praktyk wykonawczych oraz rozwiązań formalnych stosowanych we wczesnych koncertach instrumentalnych, poddają w wątpliwość pogląd, że gatunek koncertu klawiszowego jest wczesnoklasyczny od samego początku (White xii). Trzy omówione dzieła są wreszcie interesującym zjawiskiem również na tle twórczości samego Durantego - uważanego za mistrza kontrapunktu, autora mszy a cappella naśladującej styl palestrinowski, a jednocześnie zwolennika łączenia zachowawczego stile antico z nowymi wpływami, który nawet w najpóźniejszym okresie swojej działalności adaptował na bieżąco nowości stylistyczne, wprowadzane w operach przez młodych kompozytorów (Dietz 742). Jego koncerty klawiszowe wydają się tę umiejętność potwierdzać. 


\section{BIBLIOGRAFIA}

Butt, John. „Towards a Genealogy of the Keyboard Concerto”. The Keyboard in Baroque Europe, red. Christopher Hogwood, Cambridge UP, 2003, ss. 93-110.

Costantini, Danilo, i Ausilia Magaudda. „Giacomo Francesco Milano Franco d'Aragona.” Sadie, t. 16, ss. 670 .

Degrada, Francesco. „Appunti critici sui concerti di Francesco Durante”. Chigiana: Rassegna annuale di Studi musicologici, $\mathrm{nr}$ 4, 1967, ss. 145-165.

Dietz, Hanns-Bertold. „Francesco Durante”. Sadie, t. 7, ss. 739-745.

Freeman, Daniel E. „The Earliest Italian Keyboard Concertos”. The Journal of Musicology, nr 2, 1985-1986, ss. 121-145.

Harris, John M. A History of Music for Harpsichord or Piano and Orchestra. The Scarecrow Press, 2003.

Heller, Karl. „Das frühe Konzert für Tasteninstrumente in Italien und Deutschland.” Contributi musicologici del Centro Ricerche dell'AMIS, nr 10, 1997, ss. 239-254.

Kolneder, Walter. „The Solo Concerto”. The New Oxford History of Music, red. Gerald Abraham, t. 6, Oxford UP, 1986, ss. 302-376.

Maunder, Richard. The Scoring of Baroque Concertos. The Boydell Press, 2004.

Sadie, Stanley, redaktor. The New Grove Dictionary of Music and Musicians. Wyd. 2, Oxford UP, 2001. 29 tomów.

Slatford, Rodney, i Alyn Shipton. „Double bass”. Sadie, t. 7, ss. 519-525.

Stowell, Robin. „Performance practice in the eighteenth-century concerto.” The Cambridge Companion to the Concerto, red. Simon P. Keefe, Cambridge UP, 2005, ss. 192-226.

Talbot, Michael. „The Concerto Allegro in the Early Eighteenth Century II.” Music and Letters, nr 2, 1971, ss. 159-172.

White, Chappell. From Vivaldi to Viotti. A History of the Early Classical Violin Concerto. Gordon and Breach, 1994.

Zanetti, Roberto. La musica italiana nel settecento, t. 2, Bramante Editrice, 1978, ss. 1095-1102.

\section{WCZESNE WŁOSKIE KONCERTY KLAWISZOWE \\ FRANCESCA DURANTEGO}

Streszczenie

Dzieła przeznaczone na solowy instrument klawiszowy $\mathrm{z}$ towarzyszeniem orkiestry tworzą osobny nurt w gatunku koncertu instrumentalnego, mający swoje początki w pierwszej połowie osiemnastego wieku, jak wskazują zachowane źródła. Gatunek ten, uznawany za specjalność zwłaszcza kompozytorów z krajów niemieckojęzycznych, powstawał wówczas także we Włoszech. Autorem jednych z najwcześniejszych włoskich koncertów klawiszowych był działający w Neapolu Francesco Durante (1684-1755). Podczas gdy do tej pory w literaturze uwaga poświęcana bywała jedynie Koncertowi $B$-dur tego kompozytora, do naszych czasów zachowały się niekompletnie jeszcze dwa inne koncerty klawesynowe jego autorstwa, nieuwzględniane dotąd przez badaczy - Koncert A-dur i Koncert $C$-dur. Wspólnie te trzy dzieła pozwalają zaobserwować przemiany stylistyczne, jakie w epoce 
Bacha i Haendla miały miejsce na terenie Włoch, a zarazem dostarczają cennych informacji na temat historii komponowania i wykonywania koncertu klawiszowego.

Słowa kluczowe: koncert klawiszowy; Francesco Durante; muzyka włoska osiemnastego wieku; Neapol; stylistyka; controbasso.

\section{EARLY ITALIAN KEYBOARD CONCERTOS BY FRANCESCO DURANTE}

\section{S u m m a ry}

Compositions for solo keyboard with orchestral accompaniment represent a separate subgenre of the instrumental concerto, with its history (based on preserved sources) having been traced back to the first half of the eighteenth century. This subgenre, associated mostly with German composers, was also being cultivated at that time in Italy, where some of the earliest keyboard concertos were those by Francesco Durante (1684-1755), who was active in Naples. So far, only his concerto in B-flat major has received any attention in the scholarly literature, while the two other incompletely preserved harpsichord concertos by this composer - in A major and C major - have been neglected by researchers. A study of all of these three pieces together reveals stylistic changes that took place in Italy during Bach's and Haendel's era, and at the same time provides some essential information on the compositional history and performance practices of the keyboard concerto.

Keywords: keyboard concerto; Francesco Durante; 18-century Italian music; Naples; style; controbasso. 